\title{
Effect of Retransfusion After
}

\section{Hemorrhagic Hypotension on Intrarenal Distribution of Blood Flow in Dogs}

\author{
Serge Carrière and Bernard Daigneault with the technical assistance of \\ François Rochefort \\ From the Department of Medicine and Clinical Laboratories, Maisonneuve \\ Hospital, and the University of Montreal, Montreal, Canada
}

A B S TRACT Hemorrhagic hypotension in anesthetized dogs produces a marked decrease of the cortical blood flow, whereas the medullary blood flow is well preserved. These animals were maintained at blood pressures of $50 \mathrm{~mm} \mathrm{Hg}$ during a $3 \mathrm{hr}$ period after which their blood pressures were restored by the reinfusion of blood or dextran, or both. In the first group of animals, the reinfusion of blood reestablished the blood pressure to control values, but the cortical blood flow was still nonuniformly decreased whereas the medullary blood flow appeared to be increased. In the second group of animals, phenoxybenzamine failed to protect the kidney completely since after blood reinfusion, the same anomalies described for the preceding group were found in 7 out of 10 dogs. The animals of the third group were reinfused with $50 \%$ of the shed blood and $10 \mathrm{ml} / \mathrm{kg}$ of a $10 \mathrm{~g} / 100 \mathrm{ml}$ solution of low molecular weight dextran. The modifications of the intrarenal distribution of the blood flow were less marked in this group although the blood flow rate of the inner cortex and the outer medulla was always elevated under these conditions. The reinfusion of low molecular weight dextran alone $(20 \mathrm{ml} / \mathrm{kg}$ of a $10 \mathrm{~g} / 100$ $\mathrm{ml}$ solution) restored the blood pressure to levels slightly lower than those observed under control conditions but reestablished a normal pattern of intrarenal blood flow. The reinfusion of high molecular weight dextran was inefficient in correcting completely the anomalies of the renal blood flow. Mechanisms such as the increased sympathetic tone, the liberation of angiotensin, and the intravascular cellular aggregation could possibly account

This paper was presented in part at the Fourth International Congress of Nephrology in Stockholm, Sweden, 24 June 1969.

Received for publication 4 May 1970 and in revised form 13 July 1970. for the persisting anomalies of the renal circulation after reinfusion and are discussed.

\section{INTRODUCTION}

An increased renal vascular resistance has been observed repeatedly during hemorrhagic hypotension (16). Most studies are in agreement that the renal blood flow decreased more proportionately than the fall in blood pressure. This is true not only during hypotension but even after the reinfusion of blood when the renal vascular resistance remains elevated for some time following restoration of blood pressure to normal values (6-9). The cortical ischemia observed during the hypotensive period (10-13) readily explains the reduced renal blood flow since the outer medullary blood flow is relatively well maintained during hemorrhagic hypotension $(11,12)$. This last point, however, is still subject to controversy $(10,13)$.

The data concerning the intrarenal distribution of the blood flow after restoration of blood pressure following hemorrhagic hypotension are sparse $(12,13)$ and incomplete. In these studies, no definite conclusions could be established concerning the modifications of the cortical circulation because of the inconsistent results obtained in a small number of experiments. On the other hand, Aukland suggested that the outer medullary hydrogen clearance is increased to values which are comparable to control conditions by reinfusion of blood after hemorrhagic hypotension.

In the present study, the modifications of the cortical and medullary circulation have been evaluated in animals submitted to hemorrhagic hypotension and in whom the blood volume and blood pressure were restored by reinfusion of blood or dextran, or both. 


\section{METHODS}

Fasted, mongrel dogs $(20-30 \mathrm{~kg})$ were anesthetized with pentobarbital $(25-30 \mathrm{mg} / \mathrm{kg})$ and were given additional doses as required during the experiments. The stem of a $\mathrm{Y}$-shaped cannula was introduced into a femoral artery; one end was connected to a Statham strain gauge for pressure recording, while the second was connected with siliconized Tygon tubing to a sterile siliconized glass reservoir into which the animal was bled. Both renal arteries were exposed through flank incisions and catheterized with polyvinyl chloride catheters by a method previously described (14). Once the surgical preparation was completed, a $30 \mathrm{~min}$ waiting period was allowed before the first krypton-85 disappearance curve was recorded under control conditions.

For the measurement of the intrarenal distribution of blood flow, $\mathrm{Kr}^{85}$ dissolved in $0.2-0.5 \mathrm{ml}$ of saline $(0.85$ $\mathrm{g} / 100 \mathrm{ml}$ ) was injected rapidly through a double-barreled adapter into the renal artery catheter followed immediately by $0.2 \mathrm{ml}$ of saline. The wash-out of the gas from the kidney during the control and experimental curves was monitored for $60 \mathrm{~min}$ using a scintillation probe with a sodium iodide crystal placed over the kidney. The detector was coupled to a scaler and a digital printer; the data were plotted on semilogarithmic graph paper. The multiexponential decay curves were analyzed graphically by the method originally described by Thorburn, Kopald, Herd, Hollenberg, O'Morchoe, and Barger (15). Under normal conditions, four different components are found by graphical analysis of the curves. These represent the blood flow rates of the cortex, the outer medulla, the inner medulla, and the perirenal and hilar fat. The blood flow rates may be calculated from the slopes of the component lines

$$
\mathrm{F}=\frac{\mathrm{k} \times \gamma \times 100}{\rho}
$$

where $\mathrm{F}$ is the flow rate in $\mathrm{ml} / 100 \mathrm{~g}$ per $\min , \mathrm{k}$ is the slope of the line, $\gamma$ the partition coefficient for $\mathrm{Kr}^{85}$ between tissue and blood (1.0), and $\rho$ the specific gravity of the tissue. The percentages of radioactivity entering into each region were determined from the zero time intercepts.

All the curves in the different phases of the experiment were recorded from the same kidney; the other kidney was used only at the end of the experiment for radioautographic studies. Once the control $\mathrm{Kr}^{85}$ curve was obtained, the animals were heparinized and allowed to bleed freely into the reservoir until blood pressure began to decrease and then more slowly until the blood pressure fell to $50 \mathrm{~mm} \mathrm{Hg}$. In most animals, as previously reported, blood pressure was lowered to $50 \mathrm{~mm} \mathrm{Hg}$ in $15-30 \mathrm{~min}$, after a loss of $20-40 \%$ of blood volume. The reservoir was then adjusted intermittently to maintain the blood pressure at $50 \mathrm{~mm} \mathrm{Hg}$ throughout the remainder of the hypotensive period. During the period in which blood pressure was stable at $50 \mathrm{~mm} \mathrm{Hg}$, the animals lost an additional 15-20\% of the initial blood volume. A second $\mathrm{Kr}^{85}$ disappearance curve was recorded $60 \mathrm{~min}$ after the start of the hemorrhage, when bleeding had stopped and the blood pressure was stable. Approximately $3 \mathrm{hr}$ after the start of the hemorrhage, the blood volume of the animal was restored in the following five different ways.

In group I, the animals were reinfused with their own shed blood within 15-20 min.

In group II, seven animals received a constant infusion of phenoxybenzamine (POB) $(100 \mu \mathrm{g} / \mathrm{min})$ into the catheter of the kidney in which the $\mathrm{Kr}^{85}$ curves were recorded, and four animals received $200 \mu \mathrm{g} / \mathrm{min}$ of $\mathrm{POB}$ intravenously. These infusions were started $15 \mathrm{~min}$ before the beginning of the hemorrhage, and they continued until the end of the experiment. To verify the adequacy of the adrenergic blockade obtained with $\mathrm{POB}$, norepinephrine (1 or $2 \mathrm{mg}$ ) was injected intravenously in four dogs similarly prepared, either by the intrarenal or the intravenous infusion of $\mathrm{POB}$, and no blood pressure changes were observed. As in the previous group, these dogs were reinfused with their own blood within the same period of time.

Group III animals were reinfused with $50 \%$ of the shed blood, and in addition, they received low molecular weight dextran (Rheomacrodex; $10 \mathrm{ml} / \mathrm{kg}$ of a $10 \mathrm{~g} / 100 \mathrm{ml}$ solution).

Group IV animals received only low molecular weight dextran (LMWD) $(20 \mathrm{ml} / \mathrm{kg}$ of a $10 \mathrm{~g} / 100 \mathrm{ml}$ solution) within 15-20 $\mathrm{min}$.

Group V animals received $20 \mathrm{ml} / \mathrm{kg}$ of a $6 \%$ dextran solution of a mean molecular weight of 80,000 during the same period of time as in the preceding group.

After the blood pressure was restored, which was approximately $3 \frac{1}{2} \mathrm{hr}$ after the start of the hemorrhage, $\mathrm{Kr}^{85}$ curves were repeated one or more times.

At the end of the experiment, the same amount of $\mathrm{Kr}^{85}$ was injected into the renal artery catheters, and the two kidneys were removed simultaneously at predetermined times after the injection. The kidneys were then immediately frozen in a mixture of dry ice and acetone, and slices were prepared for radioautograms in order to localize anatomically the different components of the $\mathrm{Kr}^{85}$ curves as previously described (15).

\section{RESULTS}

In these experiments the $\mathrm{Kr}^{85}$ disappearance curves have been recorded for $60 \mathrm{~min}$, but only the blood flow rates and the percentages of initial radioactivity derived from the first two components will be presented, for reasons previously discussed (16).

Tables I-V indicate that the control data for the cortex and the outer medulla, as calculated from the krypton disappearance curves, are comparable to those previously reported $(11,15,16)$. The modifications of the intrarenal distribution of blood flow during hemorrhagic hypotension illustrated in Tables $\mathrm{I}-\mathrm{V}$ are in agreement with the previously published results obtained by using these methods $(11,12)$. Indeed, in some experiments, a smaller proportion of the cortex (cortex A) had a normal blood flow rate during hemorrhagic hypotension as indicated by the reduced amount of activity penetrating the first rapid component. In other experiments, much of the $\mathrm{Kr}^{85}$ was distributed into regions of the cortex (cortex B) which were perfused at a rate so similar to the rate of the outer medulla that only a single blood flow rate was found for these two areas by graphical analysis.

Group I. The reinfusion of the shed blood into these animals restored the arterial blood pressure to values comparable to those observed during the control conditions (Table I). However, the cortical blood flow was 
TABLE I

Summary of Blood Flow Rates ( $\mathrm{ml} / 100 \mathrm{~g}$ per min) and Initial Distribution of Radioactivity (\% counts)

in Renal Cortex and Outer Medulla before and during Hemorrhagic Hypotension

and after Blood Reinfusion in Heparinized Dogs

\begin{tabular}{|c|c|c|c|c|c|c|c|c|c|c|c|c|c|c|c|c|}
\hline \multirow[b]{4}{*}{ Dog } & & & & & \multicolumn{3}{|c|}{ Hemorrhagic hypotension } & \multirow{2}{*}{\multicolumn{9}{|c|}{ After blood reinfusion }} \\
\hline & & \multirow{2}{*}{\multicolumn{3}{|c|}{ Control }} & \multirow[b]{3}{*}{$\begin{array}{c}\text { Cortex } \\
\text { A }\end{array}$} & \multirow{3}{*}{$\begin{array}{c}\text { Outer } \\
\text { medulla } \\
\text { and } \\
\text { Cortex } \\
\text { B }\end{array}$} & \multirow[b]{3}{*}{ B.P. } & & & & & & & & & \\
\hline & & & & & & & & \multicolumn{3}{|c|}{$15-75 \min \ddagger$} & \multicolumn{3}{|c|}{$85-145 \mathrm{~min}$} & \multicolumn{3}{|c|}{$160-220 \mathrm{~min}$} \\
\hline & & Cortex & $\begin{array}{c}\text { Outer } \\
\text { medulla }\end{array}$ & B.P.* & & & & Cortex & $\begin{array}{l}\text { Outer } \\
\text { medulla }\end{array}$ & B.P. & Cortex & $\begin{array}{c}\text { Outer } \\
\text { medulla }\end{array}$ & B.P. & Cortex & $\begin{array}{c}\text { Outer } \\
\text { medulla }\end{array}$ & B.P. \\
\hline 1 & $\begin{array}{l}\text { Flow } \\
\% \text { counts }\end{array}$ & $\begin{array}{r}830 \\
86\end{array}$ & $\begin{array}{r}100 \\
12\end{array}$ & 125 & $\begin{array}{r}755 \\
22\end{array}$ & $\begin{array}{r}142 \\
67\end{array}$ & 50 & $\begin{array}{r}770 \\
84\end{array}$ & $\begin{array}{r}140 \\
13\end{array}$ & 130 & $\begin{array}{r}695 \\
66\end{array}$ & $\begin{array}{r}197 \\
30\end{array}$ & 125 & $\begin{array}{r}830 \\
70\end{array}$ & $\begin{array}{r}220 \\
27\end{array}$ & 120 \\
\hline 2 & $\begin{array}{l}\text { Flow } \\
\% \text { counts }\end{array}$ & $\begin{array}{r}690 \\
82\end{array}$ & $\begin{array}{r}111 \\
13\end{array}$ & 125 & & $\begin{array}{l}91 \\
84\end{array}$ & 50 & $\begin{array}{r}600 \\
32\end{array}$ & $\begin{array}{r}220 \\
59\end{array}$ & 120 & $\begin{array}{r}740 \\
44\end{array}$ & $\begin{array}{r}230 \\
48\end{array}$ & 120 & $\begin{array}{r}520 \\
73\end{array}$ & $\begin{array}{r}130 \\
20\end{array}$ & 85 \\
\hline 3 & $\begin{array}{l}\text { Flow } \\
\% \text { counts }\end{array}$ & $\begin{array}{r}830 \\
79\end{array}$ & $\begin{array}{r}160 \\
18\end{array}$ & 120 & $\begin{array}{r}920 \\
70\end{array}$ & $\begin{array}{r}143 \\
22\end{array}$ & 50 & $\begin{array}{r}695 \\
79\end{array}$ & $\begin{array}{r}180 \\
17\end{array}$ & 130 & $\begin{array}{r}695 \\
56\end{array}$ & $\begin{array}{r}150 \\
42\end{array}$ & 120 & $\begin{array}{r}1380 \\
35\end{array}$ & $\begin{array}{r}190 \\
60\end{array}$ & 120 \\
\hline 4 & $\begin{array}{l}\text { Flow } \\
\% \text { counts }\end{array}$ & $\begin{array}{r}695 \\
83\end{array}$ & $\begin{array}{r}175 \\
14\end{array}$ & 135 & & $\begin{array}{l}80 \\
88\end{array}$ & 50 & $\begin{array}{r}760 \\
33\end{array}$ & $\begin{array}{r}260 \\
63\end{array}$ & 100 & $\begin{array}{r}830 \\
68\end{array}$ & $\begin{array}{r}230 \\
28\end{array}$ & 115 & $\begin{array}{r}600 \\
61\end{array}$ & $\begin{array}{r}170 \\
34\end{array}$ & 100 \\
\hline 5 & $\begin{array}{l}\text { Flow } \\
\% \text { counts }\end{array}$ & $\begin{array}{r}600 \\
81\end{array}$ & $\begin{array}{r}150 \\
17\end{array}$ & 110 & $\begin{array}{r}350 \\
20\end{array}$ & $\begin{array}{r}180 \\
71\end{array}$ & 50 & $\begin{array}{r}700 \\
62\end{array}$ & $\begin{array}{r}205 \\
35\end{array}$ & 110 & & & & $\begin{array}{r}600 \\
54\end{array}$ & $\begin{array}{r}200 \\
57\end{array}$ & 115 \\
\hline 6 & $\begin{array}{l}\text { Flow } \\
\% \text { counts }\end{array}$ & $\begin{array}{r}830 \\
90\end{array}$ & $\begin{array}{r}116 \\
8\end{array}$ & 110 & & $\begin{array}{r}205 \\
93\end{array}$ & 50 & $\begin{array}{r}700 \\
70\end{array}$ & $\begin{array}{r}230 \\
27\end{array}$ & 110 & & & & $\begin{array}{r}700 \\
40\end{array}$ & $\begin{array}{r}205 \\
57\end{array}$ & 110 \\
\hline 7 & $\begin{array}{l}\text { Flow } \\
\% \text { counts }\end{array}$ & & & 125 & & $\begin{array}{r}113 \\
74\end{array}$ & 50 & $\begin{array}{r}600 \\
65\end{array}$ & $\begin{array}{r}230 \\
29\end{array}$ & 125 & & & & & & \\
\hline 8 & $\begin{array}{l}\text { Flow } \\
\% \text { counts }\end{array}$ & $\begin{array}{r}761 \\
83\end{array}$ & $\begin{array}{r}135 \\
14\end{array}$ & 130 & & & 50 & $\begin{array}{r}690 \\
60\end{array}$ & $\begin{array}{r}209 \\
34\end{array}$ & 125 & $\begin{array}{r}740 \\
58\end{array}$ & $\begin{array}{r}201 \\
37\end{array}$ & 120 & $\begin{array}{r}770 \\
55\end{array}$ & $\begin{array}{r}185 \\
40\end{array}$ & 120 \\
\hline 9 & $\begin{array}{l}\text { Flow } \\
\% \text { counts }\end{array}$ & $\begin{array}{r}600 \\
84\end{array}$ & $\begin{array}{r}104 \\
14\end{array}$ & 120 & $\begin{array}{r}520 \\
25\end{array}$ & $\begin{array}{r}170 \\
68\end{array}$ & 50 & $\begin{array}{r}830 \\
64\end{array}$ & $\begin{array}{r}167 \\
33\end{array}$ & 110 & & & & & & \\
\hline Flow & mean) & $\begin{array}{r}730 \\
35\end{array}$ & $\begin{array}{r}131 \\
10\end{array}$ & $\begin{array}{r}122 \\
3\end{array}$ & $\begin{array}{l}636 \\
125\end{array}$ & $\begin{array}{r}140 \\
16\end{array}$ & 50 & $\begin{array}{r}705 \\
25\end{array}$ & $\begin{array}{c}2058 \\
12\end{array}$ & $\begin{array}{r}118 \\
4\end{array}$ & $\begin{array}{r}740 \\
25\end{array}$ & $\begin{array}{c}202 \| \\
15\end{array}$ & $\begin{array}{r}120 \\
2\end{array}$ & $\begin{array}{l}770 \\
109\end{array}$ & $\begin{array}{c}1868 \\
11\end{array}$ & $\begin{array}{r}110 \\
5\end{array}$ \\
\hline$\%$ c & nts (mean) & $\begin{array}{r}84 \\
1\end{array}$ & $\begin{array}{r}14 \\
1\end{array}$ & & $\begin{array}{l}348 \\
12\end{array}$ & $\begin{array}{c}71 \pi \\
8\end{array}$ & & $\begin{array}{c}618 \\
6\end{array}$ & $\begin{array}{c}349 \\
6\end{array}$ & & $\begin{array}{c}58 \pi \\
4\end{array}$ & $\begin{array}{l}37 \pi \\
4\end{array}$ & & $\begin{array}{c}55 \pi \\
5\end{array}$ & $\begin{array}{l}40 \pi \\
6\end{array}$ & \\
\hline
\end{tabular}

* Blood pressure.

¥ Time interval during which $\mathrm{Kr}^{\mathrm{ss}}$ curves were recorded.

$\$$. $\|$. I Indicate that the $P$ values from $t$ test on paired observations are, respectively, $<0.01,<0.02$, and $<0.001$ in comparison with values obtained during the control curve.

not uniformly distributed as demonstrated by the radioautogram of a kidney removed immediately after krypton injection under these conditions (Fig. 1). This radioautogram, presented with the corresponding kidney slice, shows that some areas of the cortex are well filled with krypton indicating high flow rates within these regions, whereas other regions contain smaller amounts of radioactivity indicating much slower rates of blood flow or even complete ischemia. This nonuniform distribution of the cortical blood flow demonstrated by the radioautograms is corroborated by the results obtained from the krypton-85 disappearance curves. These data illustrate (Table I) that, although the cortical blood flow rates are comparable to control values, the percentages of initial radioactivity penetrating the cortex are significantly decreased at 15,85 , or $160 \mathrm{~min}$ after blood reinfusion.

Fig. 2 illustrates the radioautogram of a kidney removed 2 min after krypton-85 injection from an ani- mal reinfused with its own shed blood in comparison to the radioautogram of a kidney removed at the same time under normal conditions. The radioactivity has already disappeared from the cortex and is localized within the region of the inner cortex and the outer medulla indicating that, under these conditions, the second component of the krypton curves corresponds to the blood flow rate of this region. The radioactivity has disappeared more rapidly from the inner cortex and outer medulla of the kidney removed after blood reinfusion, thus indicating a faster rate of blood flow in that region in comparison with control conditions. This finding is also supported by the data calculated from the $\mathrm{Kr}^{\mathrm{ss}}$ disappearance curves (Table I) which demonstrate a significant elevation of the juxtamedullary blood flow rate after blood reinfusion.

Radioautograms of kidneys removed 4 min after $\mathrm{Kr}$ injection (Fig. 3) also demonstrate that the radioactivity disappears more rapidly from the inner cortex 


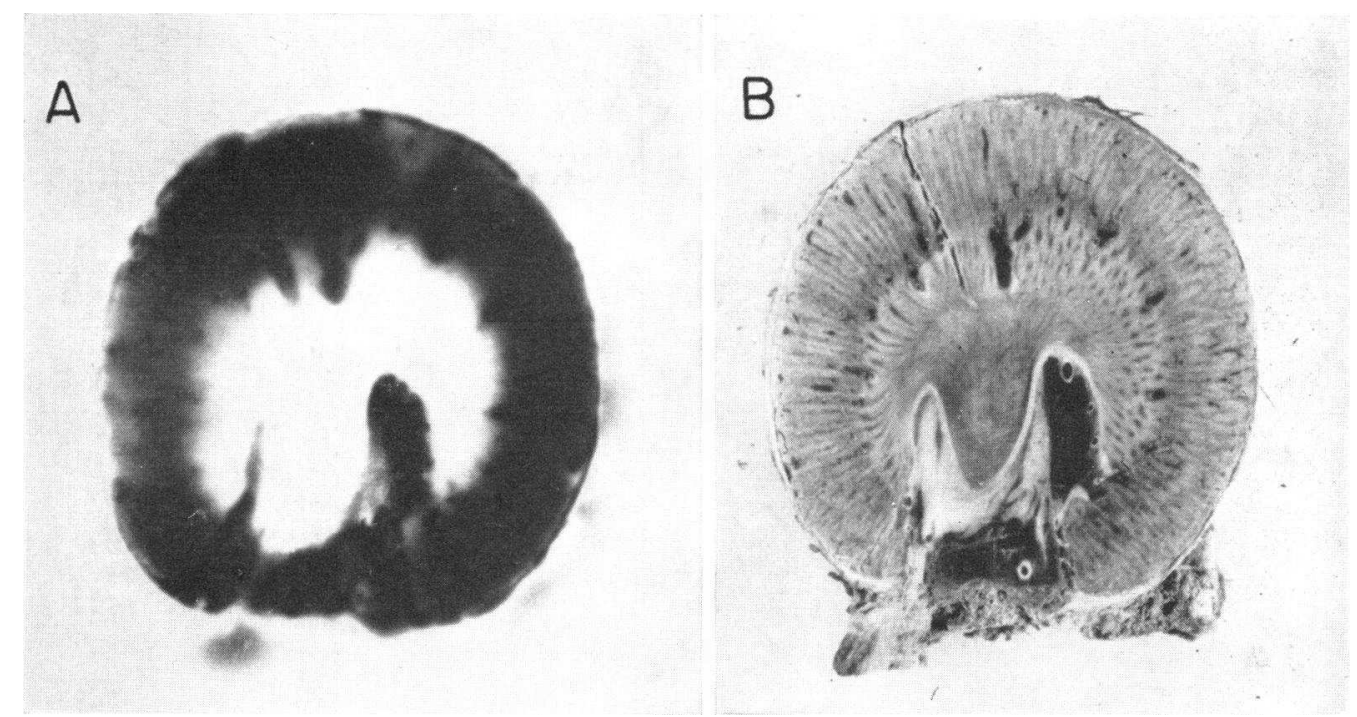

FIGURE 1 A : Radioautogram of a kidney removed immediately after intrarenal $\mathrm{Kr}^{85}$ injection from a dog reinfused with blood, showing the uneven distribution of the radioactivity.

$\mathrm{B}$ : Corresponding tissue slice.

and outer medulla after blood infusion in comparison with control conditions.

Group II. Table II demonstrates that in animals which received phenoxybenzamine during the experiment, blood reinfusion restored the blood pressure to levels that are generally lower than control values, mostly in animals observed over a period of several hours. Essentially, the same modifications of the intrarenal distribution of blood flow were found in the ani- mals of this group in comparison with the first group. The cortical blood flow rates are comparable to control conditions, and the percentages of initial radioactivity are significantly decreased as in the previous group. Fig. 4 illustrates the radioautograms of kidneys removed immediately after $\mathrm{Kr}$ injection into two different animals of this group, one kidney from a dog which received $100 \mu \mathrm{g} / \mathrm{min}$ of POB into the renal artery (Fig. $4 \mathrm{~A}$ ), and the other from a dog which received 200

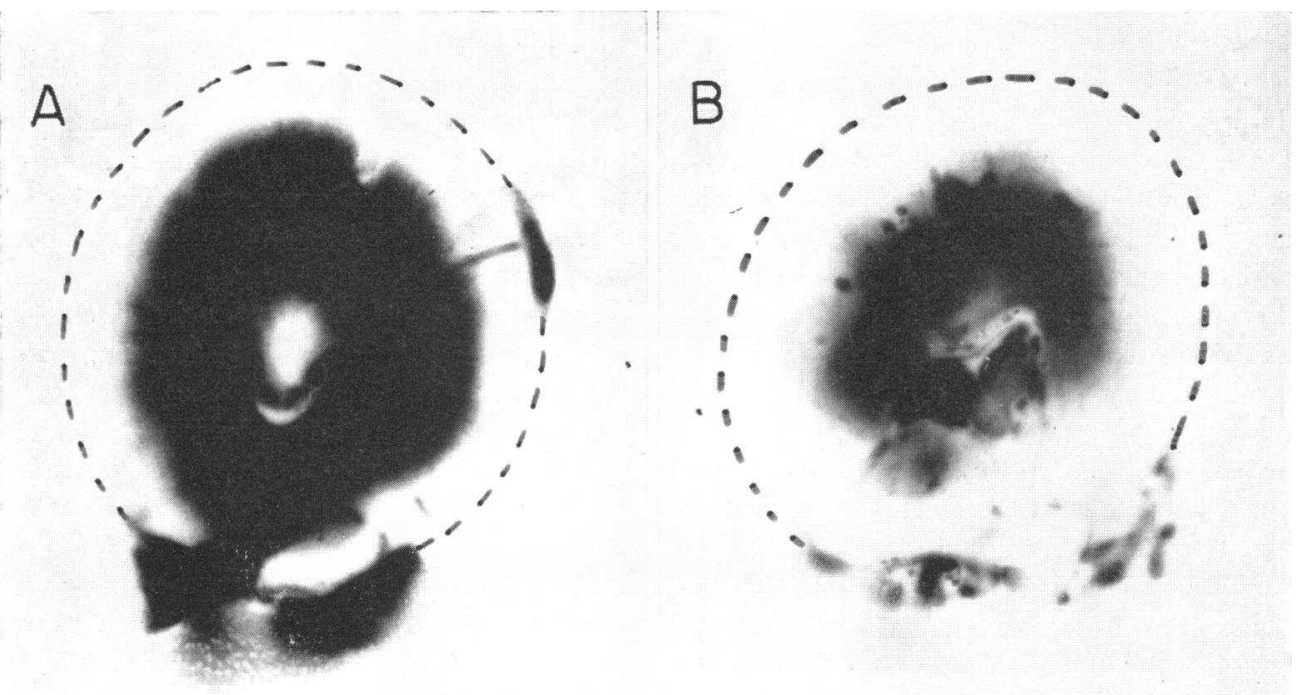

FIGURE 2 Radioautograms of kidneys removed 2 min after intrarenal $\mathrm{Kr}^{85}$ injection, showing that, in comparison with control conditions (A), the radioactivity disappears more rapidly from the inner cortex and outer medulla after blood reinfusion (B). 




FIGURE 3 Radioautograms of kidneys removed 4 min after intrarenal $\mathrm{Kr}^{85}$ injection, showing that, in comparison with control conditions (A), the radioactivity disappears more rapidly for the inner cortex and outer medulla after blood reinfusion (B).

$\mu \mathrm{g} / \mathrm{min}$ of $\mathrm{POB}$ intravenously (Fig. 4B). The uneven distribution of the radioactivity within the cortex, which in most occasions was less marked than in the preceding group (Fig. 4B), confirms the results obtained from the $\mathrm{Kr}^{\mathrm{s5}}$ curves for the cortical blood flow. As in the first group, the blood flow rate of the inner cortex and the outer medulla was increased after reinfusion. Nevertheless, in four dogs of this group (Nos. 10, 11, 19, 20) the blood flow rates and the percentages of initial radioactivity after blood reinfusion were comparable to control conditions, and the radioautograms showed a normal distribution of the radioactivity.

Group III. Table III illustrates the changes of the intrarenal distribution of blood flow in animals retransfused with $50 \%$ of the shed blood and LMWD (10 $\mathrm{ml} / \mathrm{kg}$ of $10 \mathrm{~g} / 100 \mathrm{ml}$ solution). The modifications of the cortical blood flow were less pronounced than in the previous group as indicated by the comparable or even higher values of the blood flow rates and the slight, although significant, decrease in the percentage of initial radioactivity penetrating this region. However, the blood flow rates of the inner cortex and the outer medulla were significantly elevated under these conditions in comparison with control values. The radioautograms of kidneys removed immediately after $\mathrm{Kr}$ injection in these conditions showed only slight alterations in the cortical distribution of the radioactivity. On the other hand, radioautograms of kidneys removed $2 \mathrm{~min}$ after $\mathrm{Kr}$ injection, during the second component, demonstrated that the radioactivity disappears more rapidly from the inner cortex and the outer medulla after blood and LMWD infusion than under control conditions (Fig. 5).

Group IV. The reinfusion of LMWD alone $(20 \mathrm{ml} /$ $\mathrm{kg}$ of a $10 \mathrm{~g} / 100 \mathrm{ml}$ solution) restored the blood pressure to levels slightly but not significantly, lower than those observed under control conditions (Table IV). In contrast to the results obtained in the first three groups, the cortical and medullary blood flow rates and the percentages of initial radioactivity penetrating these regions were usually comparable with the values observed before the hemorrhage. Most of the radioautograms under these conditions were comparable with those of normal kidneys. Some of these dogs, however, were observed for a longer period of time after LMWD infusion, and they showed a slight drop in blood pressure secondary to a bleeding tendency. The radioautograms in these instances demonstrated (Fig. 6) that a narrow subcapsular zone of the cortex was vasoconstricted, since immediately after the krypton injection, no radioactivity was present in that area while the rest of the cortex was highly radioactive. The results of the $\mathrm{Kr}^{85}$ decay curves recorded in those conditions were not included in Table IV since they were highly abnormal and not representative because of the secondary drop in blood pressure.

Group $V$. Table $\mathrm{V}$ demonstrates that, after the reinfusion of $6 \%$ dextran $(20 \mathrm{ml} / \mathrm{kg})$ the percentage of radioactivity in the cortex is slightly but significantly 
TABLE II

Summary of Blood Flow Rates (ml/100 g per min) and Initial Distribution of Radioactivity (\% counts) in Renal Cortex and Outer Medulla before and during Hemorrhagic Hypotension and after Blood Reinfusion in Heparinized Dogs Protected with $P O B$

\begin{tabular}{|c|c|c|c|c|c|c|c|c|c|c|c|c|c|c|c|c|}
\hline \multirow[b]{4}{*}{ Dog } & & & & & \multicolumn{3}{|c|}{ Hemorrhagic hypotension } & \multirow{2}{*}{\multicolumn{9}{|c|}{ After blood reinfusion }} \\
\hline & & \multirow{2}{*}{\multicolumn{3}{|c|}{ Control }} & \multirow[b]{3}{*}{$\begin{array}{c}\text { Cortex } \\
\text { A }\end{array}$} & \multirow{3}{*}{$\begin{array}{l}\text { Outer } \\
\text { medulla } \\
\text { and } \\
\text { Cortex } \\
\text { B }\end{array}$} & \multirow[b]{3}{*}{ B.P. } & & & & & & & & & \\
\hline & & & & & & & & \multicolumn{3}{|c|}{$15-75 \min \ddagger$} & \multicolumn{3}{|c|}{$85-145 \mathrm{~min}$} & \multicolumn{3}{|c|}{$160-220 \mathrm{~min}$} \\
\hline & & Cortex & $\begin{array}{c}\text { Outer } \\
\text { medulla }\end{array}$ & B.P.* & & & & Cortex & $\begin{array}{l}\text { Outer } \\
\text { medulla }\end{array}$ & B.P. & Cortex & $\begin{array}{l}\text { Outer } \\
\text { medulla }\end{array}$ & B.P. & Cortex & $\begin{array}{l}\text { Outer } \\
\text { medulla }\end{array}$ & B.P. \\
\hline \multirow[t]{2}{*}{$10 \S$} & Flow & 595 & 155 & 135 & & 260 & 50 & 700 & 240 & 115 & 595 & 208 & 110 & 595 & 160 & 90 \\
\hline & $\%$ counts & 80 & 17 & & & 93 & & 57 & 39 & & 62 & 33 & & 80 & 18 & \\
\hline \multirow[t]{2}{*}{11} & Flow & 595 & 173 & 125 & & 230 & 50 & 695 & 173 & 125 & 695 & 173 & 125 & 520 & 173 & 125 \\
\hline & $\%$ counts & 76 & 21 & & & 95 & & 86 & 11 & & 80 & 17 & & 80 & 15 & \\
\hline \multirow[t]{2}{*}{12} & Flow & 520 & 174 & 145 & 930 & 123 & 50 & 830 & 210 & 140 & 470 & 190 & 125 & 700 & 210 & 105 \\
\hline & $\%$ counts & 76 & 20 & & 24 & 68 & & 34 & 59 & & 29 & 55 & & 26 & 61 & \\
\hline \multirow[t]{2}{*}{13} & Flow & 415 & 123 & 140 & & 210 & 50 & 830 & 170 & 130 & & & $120 \|$ & & & \\
\hline & $\%$ counts & 84 & 15 & & & 91 & & 41 & 57 & & & & & & & \\
\hline \multirow[t]{2}{*}{14} & Flow & 600 & 130 & 110 & 520 & 200 & 50 & 700 & 190 & 110 & & & $90 \|$ & & & \\
\hline & $\%$ counts & 85 & 13 & & 49 & 49 & & 53 & 43 & & & & & & & \\
\hline \multirow[t]{2}{*}{15} & Flow & 830 & 150 & 120 & 1040 & 116 & 50 & 520 & 150 & 120 & & & & & & \\
\hline & $\%$ counts & 85 & 12 & & 25 & 64 & & 63 & 35 & & & & & & & \\
\hline \multirow[t]{2}{*}{16} & Flow & 592 & 150 & 120 & & & 50 & 712 & 188 & 110 & 585 & 190 & 100 & 605 & 181 & 100 \\
\hline & $\%$ counts & 81 & 16 & & & & & 55 & 40 & & 57 & 35 & & 62 & 31 & \\
\hline \multirow[t]{2}{*}{$17 \pi$} & Flow & 695 & 173 & 130 & & 280 & 50 & 695 & 160 & 115 & & & & & & \\
\hline & $\%$ counts & 77 & 17 & & & 95 & & 63 & 31 & & & & & & & \\
\hline \multirow[t]{2}{*}{18} & Flow & 695 & 113 & 140 & 520 & 143 & 50 & 465 & 155 & 125 & & & & & & \\
\hline & $\%$ counts & 81 & 16 & & 63 & 30 & & 52 & 42 & & & & & & & \\
\hline \multirow[t]{2}{*}{19} & Flow & 830 & 107 & 105 & 595 & 188 & 50 & 695 & 118 & 110 & & & & & & \\
\hline & $\%$ counts & 86 & 11 & & 61 & 29 & & 83 & 12 & & & & & & & \\
\hline 20 & $\begin{array}{l}\text { Flow } \\
\% \text { counts }\end{array}$ & $\begin{array}{r}1040 \\
85\end{array}$ & $\begin{array}{r}207 \\
12\end{array}$ & 140 & & $\begin{array}{r}197 \\
87\end{array}$ & 50 & $\begin{array}{r}695 \\
83\end{array}$ & $\begin{array}{r}143 \\
13\end{array}$ & 120 & & & & & & \\
\hline \multicolumn{2}{|c|}{ Flow (mean) } & 673 & 150 & 128 & 721 & $195^{* * *}$ & 50 & 685 & $172 * *$ & 120 & 586 & $190 * *$ & $112 \ddagger$ & 605 & 181 & $105 \S \S$ \\
\hline \multicolumn{2}{|c|}{ SEM } & 52 & 9 & 4 & 110 & 17 & & 33 & 10 & 3 & 46 & 7 & 6 & 37 & 11 & 7 \\
\hline \multicolumn{2}{|c|}{$\%$ counts (mean) } & 81 & 15 & & $44+t$ & $73 \ddagger \ddagger$ & & $61+\ddagger$ & $34+t$ & & $57 * *$ & $35 \ddagger \ddagger$ & & 62 & 31\|\| & \\
\hline \multicolumn{2}{|c|}{ SEM } & 1 & 1 & & 8 & 6 & & 5 & 5 & & 11 & 8 & & 13 & 11 & \\
\hline
\end{tabular}

* Blood pressure.

$\ddagger$ Time interval during which $\mathrm{Kr}^{85}$ curves were recorded.

$\S$ Dogs $10-16$ received $100 \mu \mathrm{g} / \mathrm{min}$ of POB into the renal artery.

\|I Indicates that although the second post reinfusion curve was not recorded, the kidneys were removed only after that time interval.

Tा Dogs 17-20 received $200 \mu \mathrm{g} / \mathrm{min}$ of $\mathrm{POB}$ intravenously.

$* *, \neq \ddagger, \$ 8,\|\| \mid$ Indicate that the $P$ values from $t$ test on paired observations are, respectively $<0.05,<0.001,<0.01$, and $<0.02$ in comparison with values obtained during the control curve.

reduced. The radioautogram in Fig. 7 confirms these slight modifications of the cortical blood flow distribution. As in the first three groups, the juxtamedullary blood flow rate was significantly elevated after dextran reinfusion (Table $\mathrm{V}$ ). This finding was also confirmed by radioautographic studies which demonstrated that after dextran reinfusion the $\mathrm{Kr}^{\mathrm{ss}}$ disappeared more rapidly from the juxtamedullary region than under normal conditions.

\section{DISCUSSION}

The present experiments confirm that hemorrhagic hypotension produces important modifications of the intra- renal distribution of blood flow. Under these conditions, as described previously (11), an important diminution of the cortical blood flow was observed, accompanied by a preservation of the outer medullary blood flow. The reduction of the cortical blood flow is an agreement with the results obtained by other groups $(10,12,13)$, but the preservation of the medullary blood flow rate, although confirmed by some investigators (12), remains a subject of controversy. Interestingly enough, when hemorrhagic hypotension is produced in animals which were not heparinized but to which heparin was added to the shed blood in the reservoir we regularly observed (in five experiments) that the cortex and outer medulla 




FIGURE 4 Radioautograms of kidneys removed immediately after intrarenal $\mathrm{Kr}^{85}$ injection from dogs reinfused with blood during POB infusion; $100 \mu \mathrm{g} / \mathrm{min}$ into the renal artery (A) and $200 \mu \mathrm{g} / \mathrm{min}$ intravenously (B). The radioactivity is unevenly distributed within the cortex.

TABLE III

Summary of Blood Flow Rates (ml/100 g per min) and Initial Distribution of Radioactivity (\% counts) in Renal Cortex and Outer Medulla before and during Hemorrhagic Hypotension and after Blond* and LMWD Reinfusion in Heparinized Dogs

\begin{tabular}{|c|c|c|c|c|c|c|c|c|c|c|}
\hline \multirow[b]{3}{*}{ Dog } & & \multirow{2}{*}{\multicolumn{3}{|c|}{ Control }} & \multicolumn{3}{|c|}{ Hemorrhagic hypotension } & \multicolumn{3}{|c|}{ After blood and LMWD reinfusion } \\
\hline & & & & & \multirow[b]{2}{*}{ Cortex A } & \multirow{2}{*}{$\begin{array}{l}\text { Outer } \\
\text { medulla } \\
\text { and } \\
\text { Cortex B }\end{array}$} & \multirow[b]{2}{*}{ B.P. } & \multicolumn{3}{|c|}{$15-75 \mathrm{~min}$} \\
\hline & & Cortex & $\begin{array}{l}\text { Outer } \\
\text { medulla }\end{array}$ & B.P.* & & & & Cortex & $\begin{array}{l}\text { Outer } \\
\text { medulla }\end{array}$ & B.P. \\
\hline \multirow[t]{2}{*}{21} & Flow & 520 & 130 & 125 & 830 & 190 & 50 & 640 & 180 & 115 \\
\hline & $\%$ counts & 82 & 15 & & 16 & 76 & & 72 & 24 & \\
\hline \multirow[t]{2}{*}{22} & Flow & 600 & 138 & 125 & 520 & 147 & 50 & 1050 & 270 & 130 \\
\hline & $\%$ counts & 85 & 12 & & 18 & 70 & & 81 & 18 & \\
\hline \multirow[t]{2}{*}{23} & Flow & 490 & 100 & 115 & 460 & 160 & 50 & 640 & 220 & 115 \\
\hline & $\%$ counts & 83 & 14 & & 49 & 47 & & 65 & 32 & \\
\hline \multirow[t]{2}{*}{24} & Flow & 350 & 106 & 125 & 416 & 148 & 50 & 755 & 173 & 115 \\
\hline & $\%$ counts & 84 & 12 & & 57 & 37 & & 82 & 14 & \\
\hline \multirow[t]{2}{*}{25} & Flow & 595 & 115 & 125 & 555 & 165 & 50 & 830 & 207 & 125 \\
\hline & $\%$ counts & 90 & 5 & & 21 & 72 & & 81 & 16 & \\
\hline \multirow[t]{2}{*}{26} & Flow & 555 & 126 & 95 & 595 & 188 & 50 & 830 & 250 & 105 \\
\hline & $\%$ counts & 87 & 10 & & 66 & 29 & & 62 & 34 & \\
\hline \multirow[t]{2}{*}{27} & Flow & 595 & 116 & 95 & 765 & 197 & 50 & 695 & 138 & 75 \\
\hline & $\%$ counts & 89 & 8 & & 60 & 36 & & 80 & 14 & \\
\hline \multirow[t]{2}{*}{28} & Flow & 695 & 110 & 105 & & 218 & 50 & 765 & 154 & 115 \\
\hline & $\%$ counts & 87 & 9 & & & 91 & & 66 & 26 & \\
\hline \multicolumn{2}{|c|}{ Flow (mean) } & 550 & 117 & 114 & 592 & 1769 & 50 & $775 \pi$ & $199 \pi$ & 112 \\
\hline \multicolumn{2}{|c|}{ SEM } & 36 & 5 & 5 & 58 & 9 & & 47 & 16 & 6 \\
\hline \multirow{2}{*}{\multicolumn{2}{|c|}{$\begin{array}{l}\% \text { counts (mean) } \\
\text { SEM }\end{array}$}} & 86 & 11 & & $41 \pi$ & 579 & & 739 & $22 \pi$ & \\
\hline & & 1 & 1 & & 8 & 8 & & 3 & 3 & \\
\hline
\end{tabular}

* Reinfusion of $50 \%$ of the shed blood.

$\ddagger$ Low molecular weight dextran $(10 \mathrm{ml} / \mathrm{kg}$ of a $10 \%$ solution $)$.

\& Blood pressure.

II Time interval during which $\mathrm{Kr}^{85}$ curve was recorded.

I Indicates that the $P$ value from $t$ test on paired observations is $<0.001$, in comparison with values obtained during the control curve. 




FIGURE 5 Radioautograms of kidneys removed 2 min after intrarenal $\mathrm{Kr}^{85}$ injection, showing that, in comparison with control conditions (A), the radioactivity disappears more rapidly from the inner cortex and outer medulla after blood and LMWD reinfusion (B).

were perfused at a much slower rate in comparison with control conditions (Table VI).

When the blood volume and the arterial blood pressure are restored by reinfusion of the shed blood after hemorrhagic hypotension, several investigators (6-9, 13) have reported that the renal resistance remained above control levels and that the total renal blood flow was reduced. The diminution of the outer cortical blood flow observed in the present experiments readily explains the increased renal resistance and the decreased renal blood flow while, in contrast, the blood flow rate of the inner cortex and the outer medulla is increased. Kramer (10) also suggested that during the postinfusion period, the blood flow through the cortex only partly recovers, although his results for the medullary blood flow differ from those of the present investigation. Aukland and Wolgast (13) also noticed in dogs that the reinfusion of blood after 2-3 $\mathrm{hr}$ of hypotension did not restore the total renal blood flow to values which were comparable with those of the control conditions. Using the hydrogen desaturation technique, they noticed on many occasions that the outer medullary hydrogen clearance was at a higher level after reinfusion. This finding would suggest that the cortical blood flow was reduced and would account for the reduced total renal blood flow as found in the present experiments.

These results also suggest that the decreased vascular resistance of the inner cortex and the outer medulla observed during hemorrhagic hypotension (11) may persist for some time following the restoration of the ar- terial blood pressure by blood reinfusion. The increased blood flow rate of that region after reinfusion is well documented by the $\mathrm{Kr}^{\mathrm{s5}}$ disappearance curves and the radioautograms which clearly demonstrate that the radioactivity disappears more rapidly from the inner cortex and the outer medulla in comparison with control conditions (Figs. 2-3).

A few possibilities have been explored in order to elucidate the mechanisms responsible for the redistribution of the intrarenal blood flow under these conditions. The increased renal resistance during hemorrhagic hypotension is accompanied by elevated blood levels of catecholamines (17), and their persistance in the blood after reinfusion (8) could explain the modifications of the renal circulation (16). Similarly, an increased sympathetic activity as suggested by McGiff (8) may also explain the redistribution of the intrarenal blood flow (18).

POB did not abolish the modifications of the intrarenal distribution of blood flow produced by hemorrhagic hypotension, and the cortical vasoconstriction persisted after blood reinfusion, although to a lesser extent. In some experiments (dogs Nos. 10,11, 19, 20) the blood flow rates after blood reinfusion were comparable with control values, and the radioautograms showed a normal distribution of the radioactivity within the cortex, whereas in most experiments the circulatory changes were comparable with those observed in the absence of POB infusion (Table II, Fig. 4). These results suggest that the changes in the intrarenal blood flow distri- 
TABLE IV

Summary of Blood Flow Rates (ml/100 $\mathrm{g}$ per min) and Initial Distribution of Radioactivity (\% counts)

in Renal Cortex and Outer Medulla before and during Hemorrhagic Hypotension

and after LMWD* Infusion in Heparinized Dogs

\begin{tabular}{|c|c|c|c|c|c|c|c|c|c|c|c|c|c|c|c|c|}
\hline \multirow[b]{3}{*}{ Dog } & & & & & \multicolumn{3}{|c|}{ Hemorrhagic hypotension } & \multicolumn{9}{|c|}{ After LMWD infusion } \\
\hline & & \multicolumn{3}{|c|}{ Control } & \multirow{2}{*}{\multicolumn{2}{|c|}{$\begin{array}{cc} & \text { Outer } \\
& \begin{array}{c} \\
\text { medulla } \\
\text { and }\end{array} \\
\text { ortex } & \text { Cortex } \\
\text { A } & \text { B }\end{array}$}} & \multirow[b]{2}{*}{ B.P. } & \multicolumn{3}{|c|}{$15-75 \mathrm{~min}$} & \multicolumn{3}{|c|}{$85-145 \mathrm{~min}$} & \multicolumn{3}{|c|}{$160-220 \mathrm{~min}$} \\
\hline & & Cortex & $\begin{array}{l}\text { Outer } \\
\text { medulla }\end{array}$ & B.P.† & & & & Cortex & $\begin{array}{l}\text { Outer } \\
\text { medulla }\end{array}$ & B.P. & Cortex & $\begin{array}{l}\text { Outer } \\
\text { medulla }\end{array}$ & B.P. & Cortex & $\begin{array}{l}\text { Outer } \\
\text { medulla }\end{array}$ & B.P. \\
\hline \multirow[t]{2}{*}{29} & Flow & 520 & 123 & 110 & 240 & 91 & 50 & 470 & 123 & 95 & 520 & 130 & 120 & 485 & 138 & 105 \\
\hline & $\%$ counts & 88 & 9 & & 33 & 55 & & 67 & 28 & & 86 & 12 & & 84 & 13 & \\
\hline \multirow[t]{2}{*}{30} & Flow & 470 & 95 & 130 & & & 50 & 600 & 140 & 120 & 700 & 118 & 130 & 465 & 120 & 120 \\
\hline & $\%$ counts & 83 & 15 & & & & & 82 & 16 & & 87 & 12 & & 81 & 17 & \\
\hline \multirow[t]{2}{*}{31} & Flow & 490 & 150 & 140 & & 87 & 50 & 520 & 190 & 130 & 380 & 105 & 100 & & & \\
\hline & $\%$ counts & 77 & 21 & & & 93 & & 81 & 16 & & 91 & 5 & & & & \\
\hline \multirow[t]{2}{*}{32} & Flow & 600 & 122 & 140 & 520 & 100 & 50 & 415 & 140 & 115 & 415 & 94 & 130 & 320 & 130 & 120 \\
\hline & $\%$ counts & 82 & 14 & & 10 & 77 & & 85 & 15 & & 85 & 12 & & 59 & 37 & \\
\hline \multirow[t]{2}{*}{33} & Flow & 460 & 116 & 125 & & 97 & 50 & 700 & 130 & 90 & 380 & 102 & 95 & 415 & 110 & 90 \\
\hline & $\%$ counts & 87 & 12 & & & 92 & & 83 & 15 & & 78 & 19 & & 78 & 19 & \\
\hline \multirow[t]{2}{*}{34} & Flow & 600 & 100 & 115 & & 140 & 50 & 840 & 230 & 90 & & & & & & \\
\hline & $\%$ counts & 92 & 7 & & & 94 & & 82 & 16 & & & & & & & \\
\hline \multirow[t]{2}{*}{35} & Flow & & & 120 & & 110 & 50 & 830 & 200 & 140 & & & & & & \\
\hline & $\%$ counts & & & & & 43 & & 80 & 12 & & & & & & & \\
\hline \multirow[t]{2}{*}{36} & Flow & & & 120 & & 166 & 50 & 830 & 140 & 100 & & & & & & \\
\hline & $\%$ counts & & & & & 93 & & 91 & 7 & & & & & & & \\
\hline \multirow[t]{2}{*}{37} & Flow & 640 & 104 & 105 & 460 & 110 & 50 & 600 & 134 & 115 & & & & & & \\
\hline & $\%$ counts & 92 & 7 & & 85 & 11 & & 82 & 16 & & & & & & & \\
\hline \multirow[t]{2}{*}{38} & Flow & 540 & 120 & 130 & & & 50 & 645 & 158 & 115 & & & & & & \\
\hline & $\%$ counts & 85 & 12 & & & & & 81 & 16 & & & & & & & \\
\hline \multicolumn{2}{|c|}{ Flow (mean) } & 540 & 116 & 124 & 406 & 113 & 50 & 645 & $159 \|$ & 111 & 479 & 110 & 115 & 421 & 124 & 109 \\
\hline \multicolumn{2}{|c|}{ SEM } & 24 & 6 & 4 & 85 & 10 & & 49 & 11 & 5 & 61 & 6 & 7 & 37 & 6 & 7 \\
\hline \multicolumn{2}{|c|}{$\%$ counts (mean) } & 86 & 12 & & 43 & $70^{* *}$ & & 81 & 16 & & 85 & 12 & & 76 & 21 & \\
\hline \multicolumn{2}{|c|}{ SEM } & 2 & 2 & & 22 & 11 & & 2 & 2 & & 2 & 2 & & 6 & 5 & \\
\hline
\end{tabular}

* Low molecular weight dextran $(20 \mathrm{ml} / \mathrm{kg}$ of a $10 \%$ solution $)$.

$\ddagger$ Blood pressure.

$\$$ Time interval during which $\mathrm{Kr}^{85}$ curves were recorded.

$\|,\|^{* *}$ Indicate that the $P$ values from $t$ test on paired observations are, respectively, $<0.02,<0.05$, and $<0.001$ in comparison with values obtained during the control curve.

bution are not due to circulating catecholamines or to increased sympathetic activity, since in animals similarly prepared the intravenous injection of large amounts of norepinephrine ( 1 and $2 \mathrm{mg}$ ) did not affect the blood pressure, demonstrating a good adrenergic blockade. Other factors which are not influenced by POB could be responsible for the circulatory changes. Indeed, the cortical vasoconstriction may be explained by the rise in angiotensin blood level stimulated by hemorrhage (19), since the action of angiotensin on the kidney is not prevented by $P O B$ (personal observation).

Mechanical factors, such as the occlusion of the arterioles by thrombosis or the aggregation of red cells in the smaller vessels of the cortex, might be responsible for the circulatory changes observed in the kidney after prolonged hypotension. Indeed, aggregation of red cells and marked reduction of blood flow in small vessels have been demonstrated in animals subjected to shock (20). Anatomical damage to the kidney was also observed under those conditions. In the present experiments, a direct visualization of the small vessels of the cortex was obviously impossible, and no direct evidence for the presence of aggregation of red cells in the capillaries either during shock or after blood transfusion could be obtained. However, histologic sections of kidneys removed from dogs several hours after blood reinfusion with or without $\mathrm{POB}$ protection demonstrated occasional thrombosis of small arterioles of the cortex (Fig. 8). These anatomical alterations correlate well with the radioautograms and the $\mathrm{Kr}^{85}$ decay curves which demonstrated that limited areas of the cortex had a reduced rate of blood flow or were completely ischemic, whereas the rest of the cortex was well perfused. 

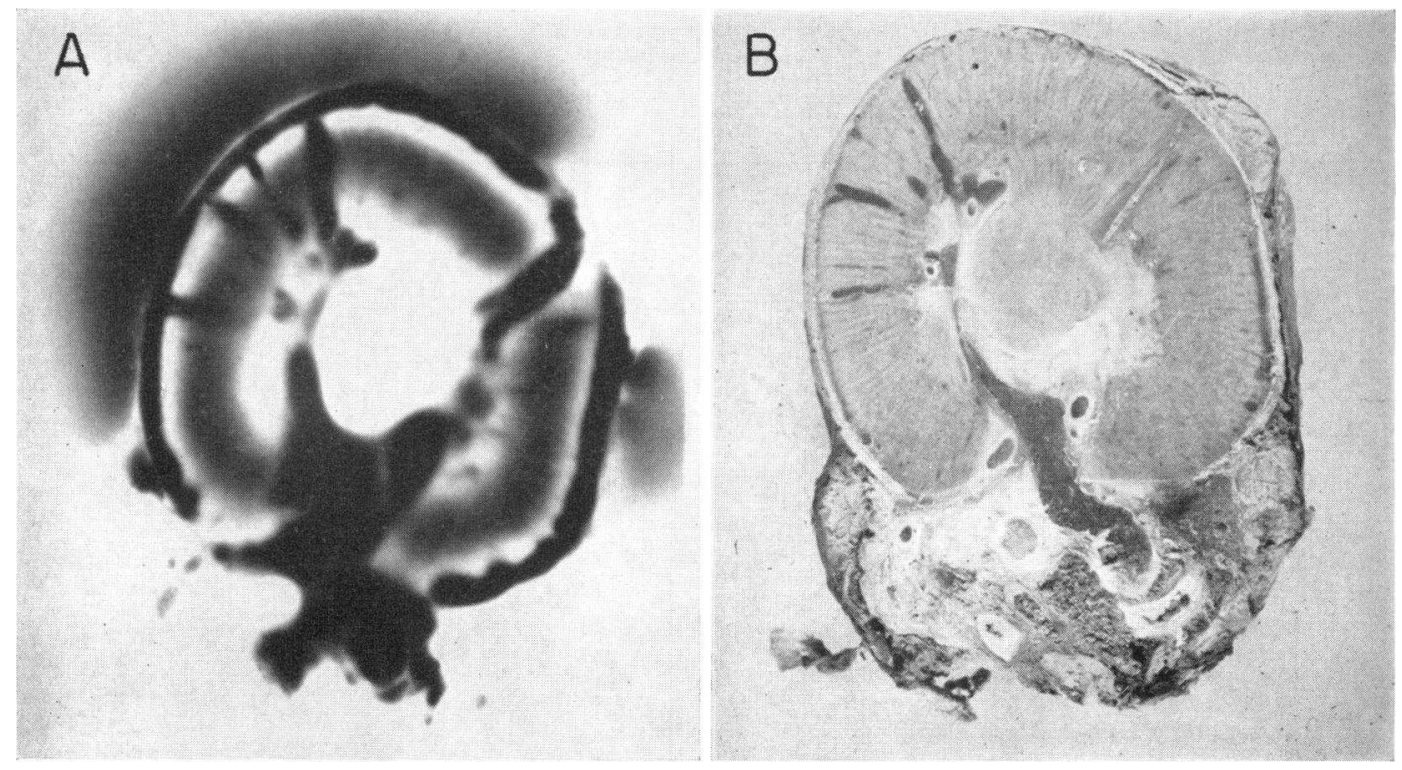

FIGURE 6 Radioautogram of a kidney removed from a dog reinfused with LMWD, demonstrating that, immediately after intrarenal $\mathrm{Kr}^{85}$ injection, no radioactivity is present in the subcapsular zone of the cortex.

B : Corresponding tissue slice.

TABLE V

Summary of Blood Flow Rates (ml/100 g per min) and Initial Distribution of Radioactivity (\% counts) in Renal Cortex and Outer Medulla before and during Hemorrhagic Hypotension and after $6 \%$ Dextran Reinfusion* in Heparinized Dogs

\begin{tabular}{|c|c|c|c|c|c|c|c|c|c|c|}
\hline \multirow[b]{3}{*}{ Dog } & & \multirow{2}{*}{\multicolumn{3}{|c|}{ Control }} & \multicolumn{3}{|c|}{ Hemorrhagic hypotension } & \multicolumn{3}{|c|}{ After $6 \%$ dextran reinfusion } \\
\hline & & & & & \multirow{2}{*}{ Cortex A } & \multirow{2}{*}{$\begin{array}{c}\text { Outer } \\
\text { medulla } \\
\text { and } \\
\text { Cortex B }\end{array}$} & \multirow[b]{2}{*}{ B.P. } & \multicolumn{3}{|c|}{$15-75 \mathrm{~min}$} \\
\hline & & Cortex & $\begin{array}{l}\text { Outer } \\
\text { medulla }\end{array}$ & B.P.§ & & & & Cortex & $\begin{array}{c}\text { Outer } \\
\text { medulla }\end{array}$ & B.P. \\
\hline \multirow[t]{2}{*}{39} & Flow & 554 & $\subseteq 9$ & 110 & 277 & 96 & 50 & 640 & 180 & 110 \\
\hline & $\%$ counts & 88 & 8 & & 57 & 25 & & 75 & 20 & \\
\hline \multirow[t]{2}{*}{40} & Flow & 695 & 115 & 110 & & 97 & 50 & 830 & 180 & 100 \\
\hline & $\%$ counts & 84 & 11 & & & 95 & & 85 & 11 & \\
\hline \multirow[t]{2}{*}{41} & Flow & 695 & 118 & 110 & 519 & 143 & 50 & 831 & 244 & 100 \\
\hline & $\%$ counts & 89 & 9 & & 72 & 24 & & 57 & 38 & \\
\hline \multirow[t]{2}{*}{42} & Flow & 695 & 112 & 140 & & 143 & 50 & 595 & 195 & 115 \\
\hline & $\%$ counts & 90 & 7 & & & 91 & & 78 & 19 & \\
\hline \multirow{2}{*}{\multicolumn{2}{|c|}{$\begin{array}{c}\text { Flow (mean) } \\
\text { SEM }\end{array}$}} & 660 & 111 & 118 & & 120 & 50 & 724 & $200 \|$ & 106 \\
\hline & & 35 & 4 & 8 & & 13 & & 62 & 15 & 4 \\
\hline \multirow{2}{*}{\multicolumn{2}{|c|}{$\begin{array}{l}\% \text { counts (mean) } \\
\text { SEM }\end{array}$}} & 88 & 9 & & & 59 & & 749 & $22 \pi$ & \\
\hline & & 1 & 1 & & & 20 & & 6 & 6 & \\
\hline
\end{tabular}

$* 20 \mathrm{ml} / \mathrm{kg}$.

$\ddagger$ Time interval during which $\mathrm{Kr}^{85}$ curve was recorded.

$\$$ Blood pressure.

II, I Indicate that the $P$ values from $t$ test on paired observations are, respectively, $<0.001$ and $<0.05$ in comparison with values obtained from the control curve. 
It has been well documented by many authors (21-24) that LMWD may reduce the intravascular cellular aggregation and increase the velocity of the microvascular flow. Moreover, it has been shown that the infusion of LMWD to animals subjected to shock may counteract the flow changes and prevent the damage to the kidney (20). The results obtained from the present experiments with dogs reinfused with LMWD, either alone or with blood, support those findings. When the animals were retransfused with a mixture of blood and LMWD the anomalies of the cortical circulation were less marked, but the blood flow rate of the inner cortex and the outer medulla was still markedly increased in comparison with control values as demonstrated by the $\mathrm{Kr}^{8 \mathrm{8}}$ curves and the radioautograms. The hematocrit of these dogs dropped by $25-30 \%$, and the viscosity of their blood probably decreased simultaneously which would account for the improvement of the renal circulation as reported for other vascular beds (23). The histologic sections of these kidneys demonstrated that the anomalies observed in the preceding group were still present but to a lesser degree as fewer instances of thrombosis were noticed.

The alterations of the cortical and medullary circulation practically disappeared when LMWD alone was infused and a further drop of the hematocrit was precipitated. These results are compatible with the observations of Gelin, Brunius, Fritjofsson, and Lewis (25) who, using the $\mathrm{Xe}^{133}$ method, demonstrated that LMWD

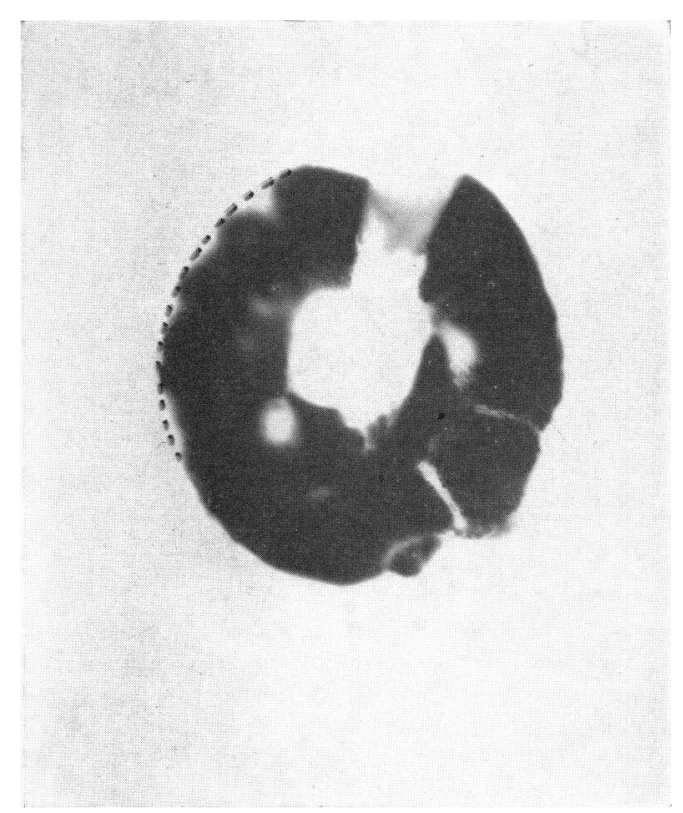

FIgURE 7 Radioautogram of a kidney removed from a dog reinfused with $6 \%$ dextran immediately after $\mathrm{Kr}^{85}$ injection, showing a slight patchiness of the cortex due to altered outer cortical blood flow.
TABLE VI

Summary of Blood Flow Rates (ml/100g per min) and Initial Distribution of Radioactivity (\% counts) in Renal Cortex and Outer Medulla before and during Hemorrhagic Hypotension in Nonheparizined Dogs

\begin{tabular}{|c|c|c|c|c|c|c|}
\hline \multirow[b]{3}{*}{ Dog } & & \multirow{2}{*}{\multicolumn{3}{|c|}{ Control }} & \multicolumn{2}{|c|}{$\begin{array}{l}\text { Hemorrhagic } \\
\text { hypotension }\end{array}$} \\
\hline & & & & & \multirow{2}{*}{$\begin{array}{c}\text { Outer } \\
\text { medulla } \\
\text { and } \\
\text { Cortex } \\
\text { A and B }\end{array}$} & \multirow[b]{2}{*}{ B.P. } \\
\hline & & Cortex & $\begin{array}{l}\text { Outer } \\
\text { medulla }\end{array}$ & B.P. & & \\
\hline \multirow[t]{2}{*}{41} & Flow & 520 & 138 & 120 & 64 & 50 \\
\hline & $\%$ counts & 81 & 14 & & 58 & \\
\hline \multirow[t]{2}{*}{42} & Flow & 595 & 189 & 140 & 51 & 50 \\
\hline & $\%$ counts & 76 & 22 & & 56 & \\
\hline \multirow[t]{2}{*}{43} & Flow & 520 & 122 & 140 & 82 & 50 \\
\hline & $\%$ counts & 85 & 12 & & 63 & \\
\hline \multirow[t]{2}{*}{44} & Flow & 690 & 198 & 115 & 60 & 50 \\
\hline & $\%$ counts & 75 & 22 & & 55 & \\
\hline \multirow[t]{2}{*}{45} & Flow & 520 & 149 & 125 & 109 & 50 \\
\hline & $\%$ counts & 85 & 12 & & 49 & \\
\hline
\end{tabular}

could increase the renal blood flow and the urine flow in the dog, despite maintained hypotension. Among other considerations, the lowering of the blood viscosity (26) and the antithrombotic effect of LMWD may preserve a high velocity of the microvascular flow under those conditions. The intravascular thromboses observed in the preceding groups were never observed on the histologic section of kidneys from animals reinfused with LMWD. On the contrary, in most instances, the vessels appeared dilated. The histologic findings indicate that mechanical intravascular phenomenom may partly explain the renal circulatory changes observed in the cortex after blood reinfusion but do not offer any better explanation for the different results observed when LMWD or dextran were reinfused, since no anatomical lesions were noticed after dextran infusion.

The narrow subcapsular cortical zone of ischemia in response to a slight drop in blood pressure after LMWD infusion was also observed during hemorrhagic hypotension (11) and after angiotensin infusion (27); this area corresponds to the aglomerular zone of the cortex which appears to react more intensively to vasoactive stimuli.

In summary, these results suggest that the increased renal vascular resistance observed after blood reinfusion which followed hemorrhagic hypotension may be explained by a reduction of the cortical blood flow rate. On the other hand, it appears that the decreased vascular resistance of the inner cortex and outer medulla observed during hemorrhagic hypotension may persist 




FIGURE 8 Photograph of a histology section from the kidney of a dog receiving POB and reinfused with his own shed blood showing a recent arteriolar thrombosis.

for some time after the restoration of the arterial blood pressure by retransfusion.

\section{ACKNOWLEDGMENTS}

We wish to express our appreciation to Mr. Andre Grenier and Albert Dupuis for their assistance and to Mr. Gerard Gagnon, Mrs. Lorraine Dagenais, and Miss Bernadette Joly for the preparation of the illustrations and the manuscript. The collaboration of Dr. L. P. LeGresley in the preparation and interpretation of the histologic sections is also appreciated.

This work was supported by grants of the Medical Research Council of Canada and the Quebec Heart Foundation.

\section{REFERENCES}

1. Smith, L. L., C. D. Reeves, and D. B. Hinshaw. 1965. Hemodynamic alterations and regional blood flow in hemorrhagic shock. In Shock and Hypotension; Patho- 
genesis and Treatment. 12th Hahnemann Symposium. L. C. Mills and J. H. Moyer, editors. Grune and Stratton, Inc., New York. 373

2. Sapirstein, L. A., E. H. Sapirstein, and A. Bredemeyer. 1960. Effect of hemorrhage on the cardiac output and its distribution in the rat. Circ. Res. 8: 135.

3. Lauson, H. D., S. E. Bradley, and A. Cournand. 1944. The renal circulatioin in shock. J. Clin. Invest. 23: 381.

4. Selkurt, E. E. 1946. Renal blood fiow and renal clearance during hemorrhagic shock. Amer. J. Prysiol. 145: 699.

5. Gregg, D. E. 1962. Hemodynamic factors in shock. In Shock: Pathogenesis and Therapy; an International Symposium, Stockholm, 1961. K. D. Bock, editor. Springer-Verlag KG., Berlin. 50.

6. Selkurt, E. E., and M. J. Elpers. 1963. Influence of hemorrhagic shock on renal hemodynamics and osmolar clearance in the dog. Amer. J. Physiol. 205: 147.

7. Abel, F. L., and Q. R. Murphy. 1962. Mesenteric, renal, and iliac vascular resistance in dogs after hemorrhage. Amer. J. Physiol. 202: 978.

8. McGiff, J. C. 1964. The renal vascular response to hemorrhage. J. Pharmacol. Exp. Ther. 145: 181.

9. Fell, C. 1966. Changes in distribution of blood flow in irreversible hemorrhagic shock. Amer. J. Physiol. 210: 863.

10. Kramer, J. 1962. Renal failure in shock. In Shock: Pathogenesis and Therapy ; an International Symposium, Stockholm, 1961. K. D. Bock, editor. Springer-Verlag KG., Berlin. 134.

11. Carrière, S., G. D. Thorburn, C. C. C. O'Morchoe, and A. C. Barger. 1966. Intrarenal distribution of blood flow in dogs during hemorrhagic hypotension. Circ. Res. 19: 167.

12. Truniger, B., S. M. Rosen, and D. E. Oken. 1966. Renale Hämodynamik and Hämorrhagische Hypotension. Klin. Wochenschr. $44: 857$.

13. Aukland, K., and M. Wolgast. 1968. Effect of hemorrhage and retransfusion on intrarenal distribution of blood flow in dogs. J. Clin. Invest. 47: 488.

14. Herd, J. A., and A. C. Barger. 1964. Simplified technique for chronic catheterization of blood vessels. J. Appl. Physiol. 19: 791.

15. Thorburn, G. D., H. H. Kopald, J. A. Herd, M. Hollenberg, C. C. C. O’Morchoe, and A. C. Barger. 1963. In- trarenal distribution of nutrient blood flow determined with Krypton ${ }^{85}$ in the unanesthetized dog. Circ. Res. 13: 290.

16. Carrière, S. 1969. Effect of norepinephrine, isoproterenol, and adrenergic blockers upon the intrarenal distribution of blood flow. Can. J. Physiol. Pharmacol. 47: 199.

17. Watts, D. T., and V. Westfall. 1964. Studies on peripheral blood catecholamine levels during hemorrhagic shock in dogs. Proc. Soc. Exp. Biol. Med. 115: 601.

18. Pomeranz, B. H., A. G. Birtch, and A. C. Barger. 1968. Neural control of intrarenal blood flow. Amer. J. Physiol. 215: 1067.

19. Scornik, O. A., and A. C. Paladini. 1964. Angiotensin blood levels in hemorrhagic hypotension and other related conditions. Amer. J. Physiol. 206: 553.

20. Gelin, L. E. 1962. Fluid substitution in shock. In Shock: Pathogenesis and Therapy; an International Symposium, Stockholm, 1961. K. D. Bock, editor. Springer-Verlag KG., Berlin. 332.

21. Long, D. M., Jr., L. Sanchez, R. L. Vargo, and C. W. Lillehei. 1961. The use of low molecular weight dextran and serum albumin as plasma expanders in extracorporeal circulation. Surgery. 50: 12.

22. Gelin, L. E., and B. Ingelman. 1961. Rheomacrodex-a new dextran solution for rheological treatment of impaired capillary flow. Acta Chir. Scand. 122: 294.

23. Lepley, D. J., C. J. Mann, and E. H. Ellison. 1962. Superior mesenteric venous occlusion: a study using low molecular weight dextran. J. Surg. Res. 2: 403.

24. Lee, W. H., Jr., and N. S. Walsh. 1965. Effect of low molecular weight dextrans on blood sludging. In Shock and Hypotension. L. C. Mills and J. H. Moyer, editors. Grune and Stratton, Inc., New York. 655.

25. Gelin, L.-E., U. Brunius, A. Fritjofsson, and D. H Lewis. 1967. Hemodilution and kidney function during shock. 4th European Conference on Microcirculation, Cambridge, 1966. Bibl. Anat. 9: 311.

26. Yao, S. T., and W. C. Shoemaker. 1966. Plasma and whole blood viscosity changes in shock and after dextran infusion. Amer. Surg. 164: 973.

27. Carrière, S., and J. Friborg. 1969. Intrarenal blood flow and PAH extraction during angiotensin infusion. Amer. J. Phy'siol. 217: 1708 . 